\title{
Unraveling the Source of Nitric Oxide Emission During Nitrification
}

\author{
Marlies J. Kampschreur*1, Cristian Picioreanu ${ }^{1}$, Nico Tan², Robbert Kleerebezem ${ }^{1}$, \\ Mike S.M. Jetten ${ }^{2}$, Mark C.M. van Loosdrecht ${ }^{1}$
}

\begin{abstract}
Nitric oxide production was measured during nitrification in a laboratory-scale bioreactor, operated at conditions relevant to municipal nitrifying wastewater treatment plants. This study aims to determine which type of microorganism and which metabolic pathway is responsible for nitric oxide emission during nitrification. Simulation studies were used to identify which pathway is the main source of nitric oxide emission, based on the following three hypothetical pathways for nitric oxide emission: (a) nitrification, (b) denitrification by ammonia-oxidizing bacteria with ammonium as electron donor, and (c) heterotrophic denitrification. The results of the study suggest that, in a nitrifying reactor treating wastewater containing solely ammonium and nutrients, denitrification by ammoniaoxidizing bacteria is the main nitric-oxide-producing pathway. During the experiments, $0.025 \%$ of the treated ammonium is emitted as nitric oxide, independent of the aeration rate imposed. Nitrite presence and oxygen limitation were found to increase the nitric oxide emission. Water Environ. Res., 79, 2499 (2007).
\end{abstract}

KEYWORDS: nitric oxide, emission, nitrification, nitrifier denitrification, ammonia oxidation, kinetic model, ammonia-oxidizing bacteria.

doi: $10.2175 / 106143007 X 220815$

\section{Introduction}

Nitric oxide is a compound with a large biological effect. It is an important atmospheric trace gas, with a direct effect on the ozone chemistry of the atmosphere (Crutzen, 1979), and it is toxic to a wide range of organisms, such as bacteria, fungi, microbial parasites, and viruses (Zumft, 1993). Because of its hydrophobicity, it can diffuse over membranes. The toxicity of nitric oxide is a consequence of its reactivity with transition metal proteins and oxygen, and, in bacteria, it has a mutagenic effect on DNA. In Eukarya, also in humans, nitric oxide is used as a messenger compound at low concentrations, but it is toxic at high levels (Marletta et al., 1990). Within the bacterial domain, nitric oxide can be produced by ammonia-oxidizing bacteria (AOB) (Lipschultz et al., 1981), nitrite-oxidizing bacteria (NOB) (Freitag and Bock, 1990), methanotrophs (Yoshinari, 1985), and denitrifying microorganisms (Firestone et al., 1979). In most bacteria, nitric oxide is produced as a byproduct and is not present in the main energygenerating pathways. In denitrifying microorganisms, nitric oxide is an intermediate of the catabolic respiratory pathway, in which nitrate or nitrite are reduced to nitrogen $\left(\mathrm{N}_{2}\right)$. The AOB can produce

\footnotetext{
${ }^{1}$ Delft University of Technology, Department of Biotechnology, Delft, The Netherlands.

${ }^{2}$ Radboud University Nijmegen, Department of Microbiology, Nijmegen, The Netherlands.

* Delft University of Technology, Department of Biotechnology, Julianalaan 67, 2628 BC Delft, The Netherlands; e-mail: M.J.Kampschreur@tudelft.nl.
}

nitric oxide either as a byproduct in the catabolic pathway, oxidizing ammonia to nitrite with oxygen, or, alternatively, by denitrification of nitrite with ammonia, hydrogen, or pyruvate as electron-donor (Colliver and Stephenson, 2000; Schmidt et al., 2004).

Nitric oxide emission can be expected from nitrifying environments, such as wastewater treatment plants (WWTPs), where AOB, $\mathrm{NOB}$, and possibly denitrifiers are present. The emission of nitric oxide was confirmed in a pilot-scale nitrifying WWTP (Stuven and Bock, 2001); however, it is not presently clear which groups of microorganisms are involved in its production. The AOB and NOB use ammonia and nitrite, respectively, as an energy source, oxygen as (main) electron acceptor, and carbon dioxide as a carbon source. Phylogenetically, $\mathrm{AOB}$ and $\mathrm{NOB}$ comprise a relatively narrow group. The AOB are clustered in the beta- and gamma-subdivision of the Proteobacteria, with the exception of the recently discovered archaeal ammonia oxidizer (Konneke et al., 2005). The NOB are assigned to the genera Nitrobacter, Nitrococcus, and Nitrospina and the more distant Nitrospira-genus (Bock and Wagner, 2001). Denitrifiers are metabolically a very diverse group of microorganisms, including both bacteria and archaea, which couple oxidation of organic or inorganic substrates to reduction of nitrate or nitrite. In this paper, heterotrophic denitrifiers are defined as any microorganism that reduces nitrate or nitrite to dinitrogen gas using chemical oxygen demand (COD) as an energy source. Often, these microorganisms are facultative denitrifiers, which only use nitrate or nitrite under oxygen limitation; otherwise, oxygen is preferred as the terminal electron acceptor.

The objective of this study is to assess which type of microorganism and which metabolic pathway is responsible for nitric oxide emission from nitrifying WWTPs. The experimental results are critically evaluated based on a mathematical model. Several hypothetical kinetic pathways are incorporated to the mathematical model and used to discriminate between the possible nitric oxide production mechanisms.

\section{Methodology}

Experimental Setup. The study was carried out in a laboratoryscale reactor containing an open (nonsterile) nitrifying culture, with a working volume of $2 \mathrm{~L}$, operated at $20^{\circ} \mathrm{C}$. The reactor was running for more than 9 months when the experiments were carried out and was inoculated with activated sludge of the B-stage of Rotterdam Dokhaven WWTP (Netherlands). The system was operated as a sequencing batch reactor (SBR) in cycles of 6 hours, as follows: 10 minutes fill phase, 307 minutes reaction phase, 3 minutes excess sludge removal, 20 minutes settling phase, and 20 minutes effluent discharge (Figure 1). Approximately $1 \mathrm{~L}$ of influent (consisting of $35 \mathrm{~mL}$ medium and $965 \mathrm{~mL}$ tap water) was fed during the fill period 


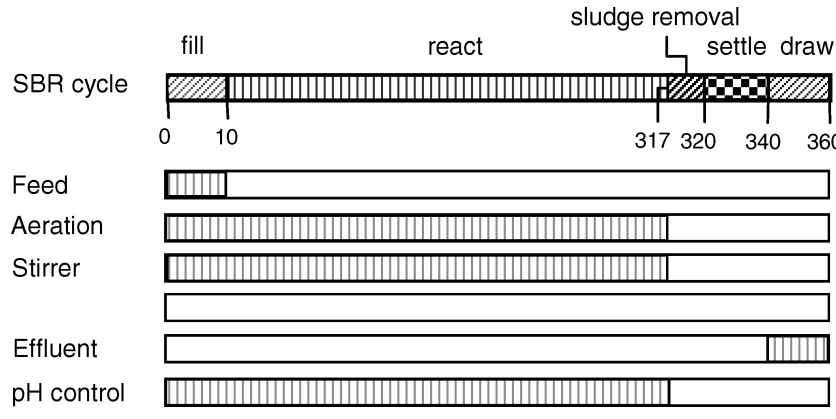

Figure 1-Schematic overview of the operational characteristics of the SBR system.

and removed during the effluent discharge period, resulting in a hydraulic retention time of 0.5 days. During the fill and reaction phase, aeration was provided, with an air flow of $0.5 \mathrm{~L} / \mathrm{min}$, and stirring was conducted at $220 \mathrm{r} / \mathrm{min}$. A constant sludge concentration in the reactor was established by sludge removal, resulting in a solids retention time (corrected for effluent suspended solids) of $9.2 \pm 2$ days. The sludge concentration in the reactor was $0.20 \pm$ $0.04 \mathrm{~g}$ dry weight $(\mathrm{dw}) / \mathrm{L}$. The biomass aggregated into sludge flocs. The sludge particle size distribution determined by automated image analysis, showed a particle size range of 1 to $100 \mu \mathrm{m}$, with a mass-based average diameter of $46 \mu \mathrm{m}$.

The nitrogen load of the reactor was $0.6 \mathrm{~kg}$ nitrogen $\mathrm{m}^{-3} \mathrm{~d}^{-1}$. The SBR was fed with a medium containing $\mathrm{NH}_{4} \mathrm{Cl}(11.45 \mathrm{~g} / \mathrm{L}), \mathrm{NaCl}$ $(5.26 \mathrm{~g} / \mathrm{L}), \mathrm{NaH}_{2} \mathrm{PO}_{4} \cdot \mathrm{H}_{2} \mathrm{O}(2.07 \mathrm{~g} / \mathrm{L}),\left(\mathrm{MgSO}_{4} \cdot 7 \mathrm{H}_{2} \mathrm{O}\right) 0.985 \mathrm{~g} / \mathrm{L}$, $\mathrm{CaCl}_{2} \cdot \mathrm{H}_{2} \mathrm{O}(0.147 \mathrm{~g} / \mathrm{L}), \mathrm{KCl}(0.835 \mathrm{~g} / \mathrm{L})$, yeast extract $(10 \mathrm{mg} / \mathrm{L})$, and trace elements solution $(0.3 \mathrm{~mL} / \mathrm{L})$. The trace elements solution contained $\mathrm{FeCl}_{3} \cdot 6 \mathrm{H}_{2} \mathrm{O}(1.5 \mathrm{~g}), \mathrm{H}_{3} \mathrm{BO}_{3}(0.15 \mathrm{~g}), \mathrm{CuSO}_{4} \cdot 5 \mathrm{H}_{2} \mathrm{O}$ $(0.03 \mathrm{~g}), \mathrm{KI}(0.18 \mathrm{~g}), \mathrm{MnCl}_{2} \cdot 4 \mathrm{H}_{2} \mathrm{O}(0.12 \mathrm{~g}), \mathrm{Na}_{2} \mathrm{MoO}_{4} \cdot 2 \mathrm{H}_{2} \mathrm{O}$ $(0.06 \mathrm{~g}), \mathrm{ZnSO}_{4} \cdot 7 \mathrm{H}_{2} \mathrm{O}(0.12 \mathrm{~g}), \mathrm{CoCl} \cdot 6 \mathrm{H}_{2} \mathrm{O}(0.15 \mathrm{~g})$, and ethylenediamine tetraacetic acid $(10 \mathrm{~g})$ in $1 \mathrm{~L}$ of demineralized water. When yeast extract was omitted, poorly settling sludge was obtained. pH control at 7.0 was established using $\mathrm{Na}_{2} \mathrm{CO}_{3}$ as a base and carbon source and $\mathrm{HCl}$ as an acid.

The treatment performance of the reactor was monitored by online measurement of the dissolved oxygen concentration and $\mathrm{pH}$ (by electrodes in the liquid), $\mathrm{Na}_{2} \mathrm{CO}_{3}$ addition for $\mathrm{pH}$ control and inorganic carbon supply, and nitric oxide and $\mathrm{NO}_{2}$ concentrations in the offgas. Nitrogen oxides in the offgas were analyzed with a Rosemount Analytical MLT-analyzer (Hasselroth, Germany) with a chemiluminescence $\mathrm{NO}_{\mathrm{x}}$ detector (detection limit for nitric oxide approximately $0.05 \mathrm{ppm}$ ). During several cycles, mixed liquor suspended solids, mixed liquor volatile suspended solids, $\mathrm{NH}_{4}{ }^{+}$, $\mathrm{NO}_{2}{ }^{-}$, and $\mathrm{NO}_{3}{ }^{-}$were analyzed offline by Standard Methods (APHA et al., 1985).

Model Development. A mathematical model was constructed to test several hypothetical sources proposed for the nitric oxide emission. The following three processes may cause nitric oxide emission from our nitrifying culture (see Discussion section for a thorough explanation): (a) escape of intermediates produced during nitrification, (b) denitrification by AOB with ammonium as electron donor, and (c) heterotrophic denitrification. When the SBR reactor was running at steady-state (stable conversion rates), the nitric oxide emission showed a regular pattern over every SBR cycle. The nitric oxide emission in the simulations of the three scenarios was used to discriminate which emission profile fits best with the experimental

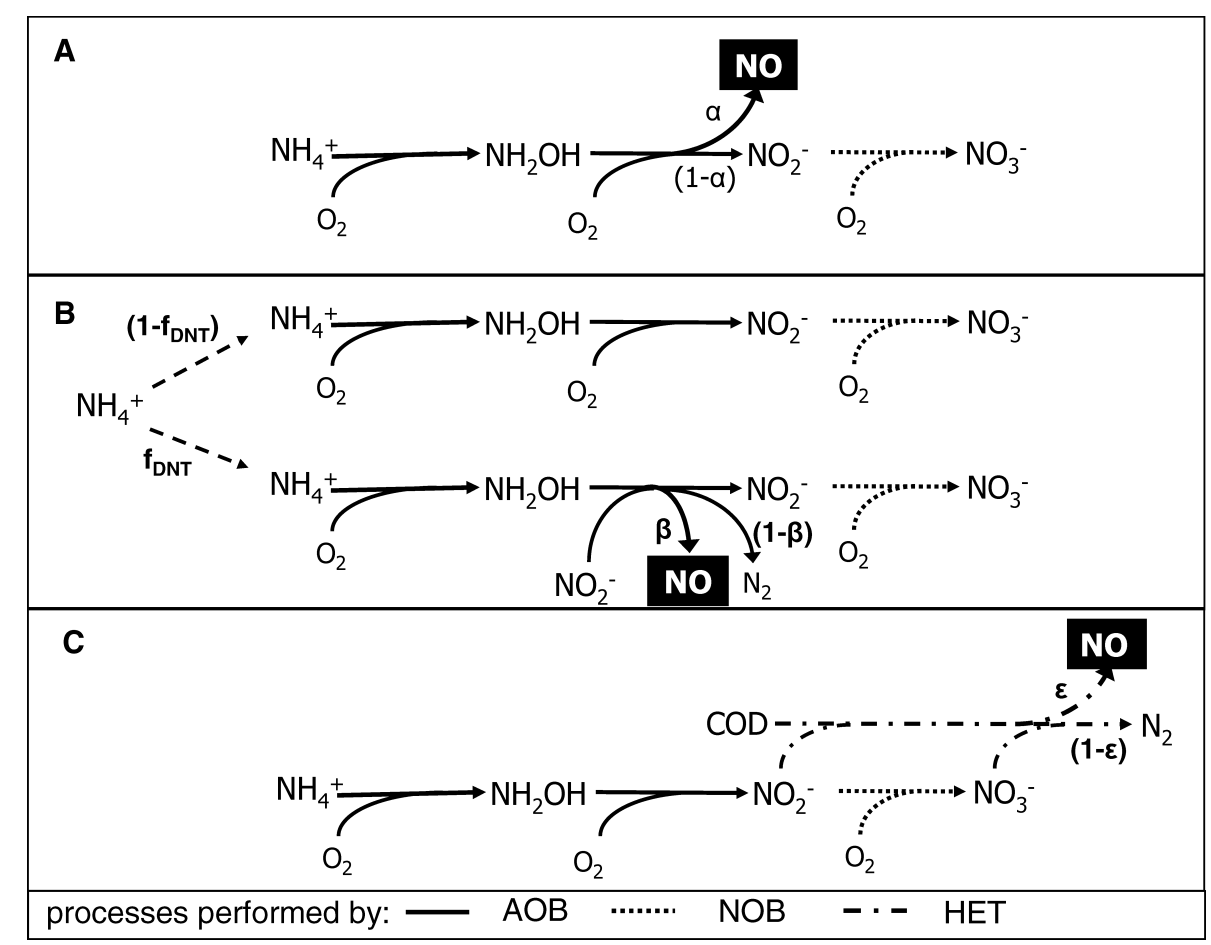

Figure 2-Schematic representation of kinetic models of the three scenarios: (a) nitric oxide emission by nitrification, (b) nitric oxide emission by denitrification by $\mathrm{AOB},(\mathrm{c})$ nitric oxide emission by denitrification by heterotrophic bacteria (HET). The nitrification intermediate hydroxylamine $\left(\mathrm{NH}_{2} \mathrm{OH}\right)$ is depicted in the scheme to clarify the degradation patterns considered, but is not included in the model. 
Table 1-Stoichiometric table of bioprocesses included in the three hypothetical scenarios for nitric oxide production.

\begin{tabular}{|c|c|c|c|c|c|c|c|c|c|c|c|}
\hline Component $\rightarrow$ & Scenario & $\mathrm{S}_{\mathrm{O} 2}$ & $S_{\mathrm{NH} 4}$ & $\mathrm{~S}_{\mathrm{NO} 2}^{-}$ & $S_{\mathrm{NO} 3-}$ & $S_{\text {NO }}$ & $S_{\mathrm{N} 2}$ & $X_{\mathrm{AOB}}$ & $X_{\text {NOB }}$ & $X_{\mathrm{HET}}$ & $x_{1}$ \\
\hline & Unit & $\mathrm{gO}_{2} / \mathrm{m}^{3}$ & $\mathrm{gN} / \mathrm{m}^{3}$ & $\mathrm{gN} / \mathrm{m}^{3}$ & $\mathrm{gN} / \mathrm{m}^{3}$ & $\mathrm{gN} / \mathrm{m}^{3}$ & $\mathrm{gN} / \mathrm{m}^{3}$ & $\begin{array}{c}\text { gCOD/ } \\
\mathrm{m}^{3}\end{array}$ & $\begin{array}{c}\text { gCOD/ } \\
\mathrm{m}^{3}\end{array}$ & $\begin{array}{c}\text { gCOD/ } \\
\mathrm{m}^{3}\end{array}$ & $\begin{array}{c}\mathrm{gCOD} / \\
\mathrm{m}^{3}\end{array}$ \\
\hline & COD/S & -1 & 0 & -3.43 & -4.57 & -2.86 & -1.71 & 1 & 1 & 1 & 1 \\
\hline Process $\downarrow$ & N/S & 0 & 1 & 1 & 1 & 1 & 0.5 & 0.11 & 0.11 & 0.11 & 0.11 \\
\hline \multicolumn{12}{|c|}{ Ammonia oxidizers } \\
\hline $\begin{array}{l}\text { 1a. Growth } \\
\mathrm{AOB} \text { on } \\
\mathrm{O}_{2}\end{array}$ & $\mathrm{~B}, \mathrm{C}$ & $1-\frac{3.43}{Y_{A O B}}$ & $-\frac{1}{\mathrm{Y}_{\mathrm{AOB}}}-i_{N B M}$ & $\frac{1}{Y_{A O B}}$ & & & & 1 & & & \\
\hline $\begin{array}{l}\text { 1b. Growth } \\
\mathrm{AOB} \text { on } \\
\mathrm{O}_{2} \text {, nitric } \\
\text { oxide via } \\
\text { oxidative } \\
\text { pathway }\end{array}$ & A & $1-\frac{(1-\alpha) \cdot 3.43}{Y_{A O B}}-\frac{\alpha \cdot 2.85}{Y_{A O B}}$ & $-\frac{1}{Y_{A O B}}-i_{N B M}$ & $\frac{(1-\alpha)}{Y_{A O B}}$ & & $\frac{\alpha}{Y_{A O B}}$ & & 1 & & & \\
\hline $\begin{array}{l}\text { 2. Decay } \\
\text { AOB }\end{array}$ & $A, B, C$ & $1-f_{p}$ & & & & & & -1 & & & $f_{p}$ \\
\hline \multicolumn{12}{|c|}{ Denitrification by $A O B$} \\
\hline $\begin{array}{l}\text { 3. Growth } \\
\mathrm{AOB} \text { on } \\
\mathrm{O}_{2} \text { and } \\
\mathrm{NO}_{2}^{-}\end{array}$ & B & $\begin{aligned} 1- & \frac{(1 / 3-4 / 3 \beta) \cdot 3.43}{Y_{A O B}} \\
& -\frac{2 \beta \cdot 2.85}{Y_{A O B}} \\
& -\frac{1 / 3(1-\beta) \cdot 1.71}{Y_{A O B}}\end{aligned}$ & $-\frac{1}{Y_{A O B}}-i_{N B M}$ & $\frac{1 / 3-4 / 3 \cdot \beta}{Y_{A O B}}$ & & $\frac{2 \cdot \beta}{Y_{A O B}}$ & $\frac{1 / 3 \cdot(1-\beta)}{Y_{A O B}}$ & 1 & & & \\
\hline \multicolumn{12}{|l|}{ Nitrite oxidizers } \\
\hline $\begin{array}{l}\text { 4. Growth } \\
\text { NOB }\end{array}$ & $A, B, C$ & $1-\frac{1.14}{Y_{\mathrm{NOB}}}$ & & $-\frac{1}{Y_{N O B}}-i_{N B M}$ & $\frac{1}{Y_{\mathrm{NOB}}}$ & & & & 1 & & \\
\hline $\begin{array}{l}\text { 5. Decay } \\
\text { NOB }\end{array}$ & $A, B, C$ & $1-f_{p}$ & & & & & & & -1 & & $f_{p}$ \\
\hline \multicolumn{12}{|c|}{ Heterotrophic denitrifiers } \\
\hline $\begin{array}{l}\text { 6. Growth } \\
\text { denitrifiers } \\
\text { on nitrate }\end{array}$ & C & & & & $\frac{-\left(1-Y_{\text {HET }}\right)}{(2.86-1.15 \cdot \varepsilon) Y_{\text {HET }}}$ & $\frac{\varepsilon \cdot\left(1-Y_{\text {HET }}\right)}{(2.86-1.15 \cdot \varepsilon) Y_{\text {HET }}}$ & $\frac{(1-\varepsilon) \cdot\left(1-Y_{\text {HET }}\right)}{(2.86-1.15 \cdot \varepsilon) Y_{\text {HET }}}$ & & & 1 & \\
\hline $\begin{array}{l}\text { 7. Growth } \\
\text { denitrifiers } \\
\text { on nitrite }\end{array}$ & C & & & $\frac{-\left(1-Y_{\text {HET }}\right)}{(1.71-1.15 \cdot \varepsilon) Y_{\text {HET }}}$ & & $\frac{\varepsilon \cdot\left(1-Y_{H}\right)}{(1.71-1.15 \varepsilon) Y_{H}}$ & $\frac{(1-\varepsilon) \cdot\left(1-Y_{\text {HET }}\right)}{(1.71-1.15 \varepsilon) Y_{\text {HET }}}$ & & & 1 & \\
\hline
\end{tabular}

data. The three scenarios are schematically presented in Figure 2; the stoichiometry of all bioconversions is in Table 1; and the rate expressions are in Table 2.

To model these three mechanisms for nitric oxide production, the nitrification process in the model was separated in two processesammonia oxidation and nitrite oxidation. This is performed by two different groups of microorganisms, $\mathrm{AOB}$ and $\mathrm{NOB}$, with concentrations $X_{A O B}$ and $X_{N O B}$. This is different from the activated sludge models (Henze et al., 1999), but it allows accumulation of nitrite during an SBR cycle, as occurs in the experimental setup. Moreover, for scenario $C$, a third biomass component is neededthe denitrifying biomass with concentration $X_{H E T}$. The network of reactions was constructed in such a way that, in all reactions, the electron (COD) and nitrogen balances are satisfied. In all cases, the nitrifying biomass concentration $\left(X_{A O B}\right.$ and $\left.X_{N O B}\right)$ reached a steadystate, governed by the rates of biomass growth, biomass removal, and decay.

In scenario A, the nitric oxide production rate is directly linked to the ammonia oxidation rate, which should be dependent on oxygen and ammonium availability. In this scenario, a fraction $\alpha$ of the nitrogen contained in $\mathrm{NH}_{4}{ }^{+}$is oxidized to nitric oxide, and the rest to nitrite. Processes 1b, 2, 4, and 5 from Tables 1 and 2 were active in scenario A.

In scenario $\mathrm{B}$, the nitric oxide production rate is dependent on the $\mathrm{AOB}$ denitrification rate, which is governed by oxygen, ammonium, and nitrite availability. The AOB denitrification occurs in parallel with the standard nitrification, and the factor $f_{\mathrm{DNT}}$ describes which fraction of ammonium is used in the denitrifying ammonia oxidation pathway. The parameter $f_{\text {DNT }}$ was assumed to be constant. This assumption is valid because, during the occurrence of denitrification by $\mathrm{AOB}$, the oxygen concentration was constant. When variable dissolved oxygen concentrations are imposed, $f_{\mathrm{DNT}}$ will increase at lower oxygen concentrations. The parameter $\beta$ represents the fraction of electrons that reduce nitrite to nitric oxide, and (1- $\beta$ ) represents the fraction of electrons that reduce nitrite to $\mathrm{N}_{2}$. The potential formation of $\mathrm{N}_{2}$ (or $\mathrm{N}_{2} \mathrm{O}$ ) was only in included in the model structure to enable future model validation; in this work, only nitric oxide was measured, and the formation of other side products was neglected by setting $\beta$ to 1 . Processes $1 \mathrm{a}, 2,3,4$, and 5 from Tables 1 and 2 were used in scenario B.

In scenario $\mathrm{C}$, the nitric oxide production is dependent on the heterotrophic denitrification rate, which is assumed to be dependent 
Table 2-Kinetic rate equations of bioprocesses included in the three hypothetical scenarios for nitric oxide production. All rates are expresses as $\mathrm{g}$ COD $\mathrm{m}^{-3} \mathrm{~d}^{-1}$.

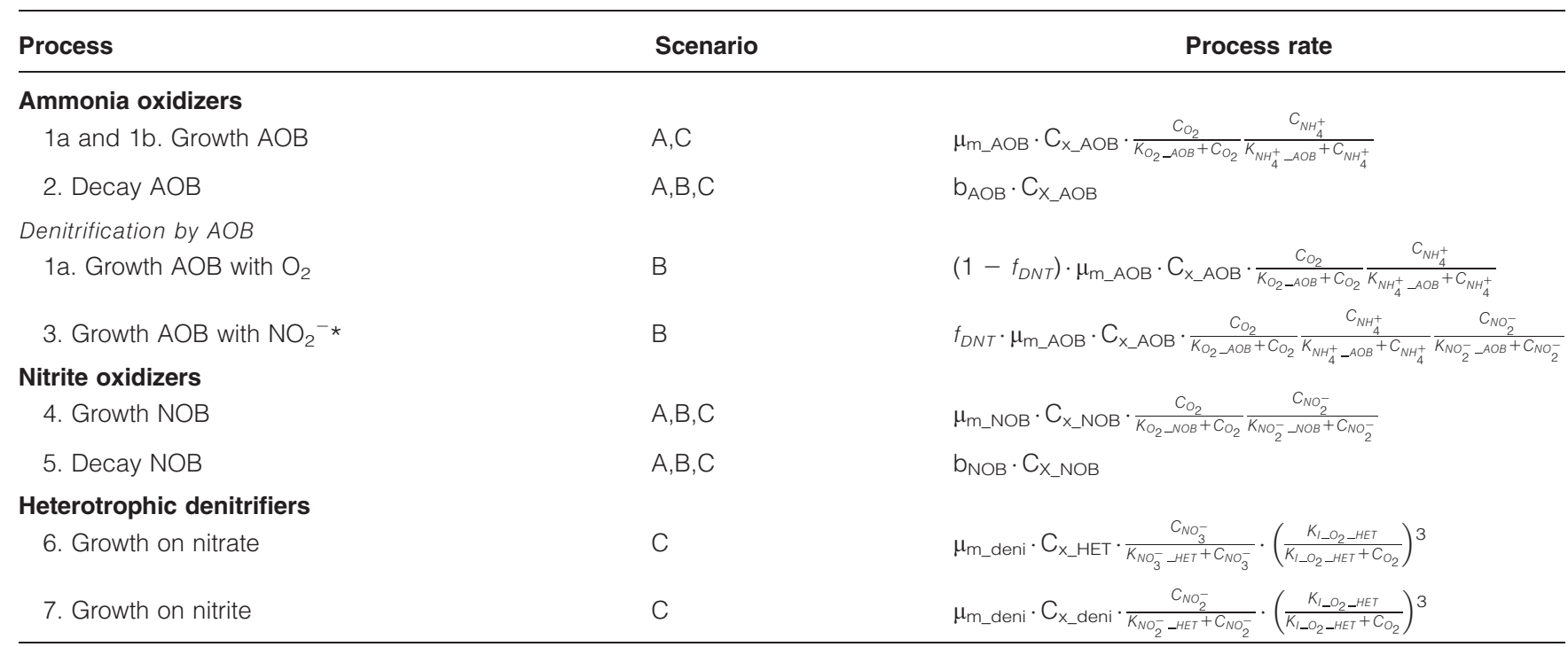

on nitrite and nitrate availability and is inhibited by oxygen presence. Because only a minor fraction of the nitrogen flux in the process $(<0.1 \%)$ ends up in nitric oxide, trace amounts of organic carbon are required as electron donor in the process. Even though no organic carbon was present in the influent, it was assumed that sufficient organic substrate could be generated-by bacterial decay or the production of extracellular polymeric substances- to neglect electron donor limitation. In the model structure, decay of denitrifying biomass (only in scenario C) was neglected to prevent usage of unnecessary processes and parameters and because of the minor amount of denitrifying biomass. Processes 1a, 2, 4, 5, 6, and 7 from Tables 1 and 2 were used in scenario C.

To obtain the time-dependent concentration profiles of all soluble and biomass components, the bioprocesses occurring in the nitrifying SBR were included in a reactor model. The model was implemented using AQUASIM software (Reichert, 1998). This is based on mass balances for all soluble and biomass components. An ideally mixed (continuously stirred tank reactor) liquid compartment of variable volume was assumed. This was connected via a diffusive link, with an ideally mixed gas compartment of constant volume. Variable liquid and gas flows during different phases of the SBR cycles were assumed and modeled according to the experimental setup using switch functions. Biomass retention was achieved by returning the biomass removed with the effluent in the draw phase back into the reactor.

The model ASM2D (Henze et al., 1999) was used as guideline for the kinetic parameters, as shown in Table 3. The experimental setup was used to define the operational parameters (Table 4). The maximum specific growth rates $\left(\mu_{\max }\right.$ values) of the ammonium and nitrite-oxidizing populations were identified by minimization of the square of the difference between the calculated and measured ammonium, nitrite, and nitrate concentrations. The biomass decay rates were made linearly dependent on the $\mu_{\max }$ values, according to $b=\mu_{\max } / 7$, as suggested by Henze et al. (1999). The parameters describing nitric oxide emission in the three scenarios investigated $(\alpha, \beta$, and $\varepsilon$ ) were estimated by minimizing the error between the measured and estimated nitric oxide concentrations in the offgas.

\section{Results}

Nitric Oxide Emission from Nitrifying Laboratory-Scale Reactor. Within 1 month after inoculation, the bioreactor reached a stable nitrogen conversion and stable biomass concentration. The concentration changes of the most important variables measured during one representative SBR cycle (6 hours) at steady-state are depicted in Figure 3. During the fill phase at the start of the cycle, ammonium was supplied to the reactor, reaching a $50 \mathrm{mg}$ nitrogen/L concentration, and the aeration was started. After aeration was started, AOB oxidized ammonium to nitrite, and nitrite was oxidized to nitrate by NOB. Nitrite oxidation was slower than ammonia oxidation, leading to the accumulation of nitrite during ammonia oxidation. After 3.8 hours, all ammonium was converted, and, after 4.5 hours, all nitrite was oxidized. The ammonium and nitrite oxidation rates were both constant during one SBR cycle (the substrate decrease and product increase were linear). Exceptions were the short lag phase just after feeding and a slower conversion at the end because of low substrate availability (the concentrations were in the same range or below the affinity values). The nitrogen balance in the liquid shows that no significant nitrogen loss occurred and that virtually all ammonium was converted into nitrate within one SBR cycle (with some small amounts of nitrogen lost as nitrogen oxides in the gas phase). The profile of the dissolved oxygen concentration in the reactor reflects the oxygen consumption rate during an SBR cycle. Because the ammonium and nitrite oxidation rates are constant, the dissolved oxygen concentration reaches a stable concentration, as long as both ammonium and nitrite are available, which is $42 \%$ saturation, or $3.5 \mathrm{mg} \mathrm{O}_{2} / \mathrm{L}$. When ammonia is depleted, the oxygen consumption is reduced and only caused by nitrite oxidation, leading to an increase in oxygen concentration. When nitrite is also depleted, oxygen is not consumed in detectable amounts.

The nitric oxide emission from the nitrifying reactor shows a reproducible pattern over an SBR cycle (Figure 3). After ammonium is supplied to the reactor, a sharp increase in nitric oxide occurs, which falls to a lower nitric oxide production level after 0.28 hours. A side experiment, in which aeration was supplied during feeding, showed a similar nitric oxide peak, suggesting that this is not a physical effect resulting from stripping of nitric oxide that may 
Table 3-Stoichiometric and kinetic parameters of the microbial conversion reactions considered.

\begin{tabular}{|c|c|c|c|c|}
\hline Definition & Symbol & Value & Unit & Reference \\
\hline \multicolumn{5}{|l|}{ Microbial kinetics } \\
\hline \multicolumn{5}{|l|}{ Aerobic ammonium oxidizers (AOB) } \\
\hline Maximum specific growth rate at $20^{\circ} \mathrm{C}\left(X_{\mathrm{AOB}}\right)$ & $\mu_{\max , \mathrm{AOB}}$ & 0.5 & $d^{-1}$ & Adjusted $^{a}$ \\
\hline Saturation coefficient for ammonium $\left(X_{\mathrm{AOB}}\right)$ & $\mathrm{K}_{\mathrm{NH} 4, \mathrm{AOB}}$ & 1 & $\mathrm{GN} \cdot \mathrm{m}^{-3}$ & ASM2d \\
\hline Saturation coefficient for oxygen $\left(X_{A O B}\right)$ & $\mathrm{K}_{\mathrm{O} 2, \mathrm{AOB}}$ & 0.5 & $\mathrm{~g} \mathrm{O}_{2} \mathrm{~m}^{-3}$ & ASM2d \\
\hline $\begin{array}{l}\text { Saturation coefficient for nitrite in denitrification } \\
\text { pathway }\left(X_{\mathrm{AOB}}\right)\end{array}$ & $\mathrm{K}_{\mathrm{NO} 2, \mathrm{AOB}, \mathrm{DN} t}$ & 8 & $\mathrm{~g} \mathrm{~N} \mathrm{~m}^{-3}$ & \\
\hline Decay rate coefficient of $X_{\mathrm{AOB}}$ & $\mathrm{b}_{\mathrm{AOB}}$ & 0.071 & $d^{-1}$ & Adjusted $^{\mathrm{a}}$ \\
\hline \multicolumn{5}{|l|}{ Aerobic nitrite oxidizers (NOB) } \\
\hline Maximum specific growth rate at $20^{\circ} \mathrm{C}\left(X_{\mathrm{NOB}}\right)$ & $\mu_{\max , \mathrm{NOB}}$ & 0.56 & $d^{-1}$ & Adjusted $^{a}$ \\
\hline Saturation coefficient for nitrite $\left(X_{N O B}\right)$ & $\mathrm{K}_{\mathrm{NO} 2, \mathrm{NOB}}$ & 3 & $\mathrm{GN} \cdot \mathrm{m}^{-3}$ & c \\
\hline Saturation coefficient for oxygen $\left(X_{\mathrm{NOB}}\right)$ & $\mathrm{K}_{\mathrm{O} 2, \mathrm{NOB}}$ & 1 & $\mathrm{~g} \mathrm{O}_{2} \mathrm{~m}^{-3}$ & d \\
\hline Decay rate coefficient of $X_{N O B}$ & $b_{\mathrm{NOB}}$ & 0.08 & $d^{-1}$ & Adjusted $^{a}$ \\
\hline \multicolumn{5}{|l|}{ Heterotrophic organisms (HET) } \\
\hline Inhibition constant for oxygen $\left(X_{\mathrm{HET}}\right)$ & $\mathrm{k}_{\mathrm{l}, \mathrm{O} 2}$ & 2 & $\mathrm{~g} \cdot \mathrm{m}^{-3}$ & Adjusted \\
\hline Saturation coefficient for nitrite $\left(X_{\mathrm{HET}}\right)$ & $\mathrm{K}_{\mathrm{NO} 2, \mathrm{HET}}$ & 8 & $\mathrm{~g} \mathrm{~N} \mathrm{~m}^{-3}$ & \\
\hline Saturation coefficient for nitrate $\left(X_{\mathrm{HET}}\right)$ & $\mathrm{K}_{\mathrm{NO}, \mathrm{HET}}$ & 0.5 & $\mathrm{~g} \mathrm{~N} \mathrm{~m}^{-3}$ & ASM2d \\
\hline Maximum specific growth rate $\left(X_{\mathrm{HET}}\right)$ & $\mu_{\max , \mathrm{HET}}$ & 5 & $d^{-1}$ & ASM2d \\
\hline \multicolumn{5}{|l|}{ Microbial stoichiometry } \\
\hline Nitrogen content of biomass & $\mathrm{i}_{\text {NBM }}$ & 0.07 & $g N \cdot g C^{-1}$ & ASM2d \\
\hline Fraction of inert COD generated in decay & $f_{P}$ & 0.2 & $\mathrm{~g} \mathrm{COD} \cdot \mathrm{g} \mathrm{COD}^{-1}$ & \\
\hline Yield for growth of ammonium oxidizers & $\mathrm{Y}_{\mathrm{AOB}}$ & 0.15 & $\mathrm{~g} \mathrm{COD} \cdot \mathrm{g} \mathrm{N}^{-1}$ & (Wiesmann, 1994) \\
\hline Yield for growth of nitrite oxidizers & $\mathrm{Y}_{\mathrm{NOB}}$ & 0.041 & $\mathrm{~g} C O D \cdot \mathrm{g} \mathrm{N}^{-1}$ & (Wiesmann, 1994) \\
\hline Yield for growth of heterotrophic organisms & $Y_{\text {HET }}$ & 0.625 & $\mathrm{~g} C O D \cdot g \mathrm{COD}^{-1}$ & ASM2d \\
\hline \multicolumn{5}{|l|}{ Nitric oxide formation } \\
\hline \multicolumn{5}{|l|}{ by ammonia oxidation by $\mathrm{AOB}$ (scenario A) } \\
\hline Fraction of ammonia converted to & & & mol nitric & \\
\hline nitric oxide during ammonia oxidation & $\alpha$ & $2.810^{-4}$ & oxide $/ \mathrm{mol} \mathrm{NH}_{4}^{+}$ & g \\
\hline \multicolumn{5}{|l|}{ by denitrification by AOB (scenario B) } \\
\hline Fraction of nitrite converted to nitric oxide & & & mol nitric & \\
\hline by denitrification by $\mathrm{AOB}$ & $\beta$ & 1 & oxide/mol NO-- & g \\
\hline Fraction of ammonia oxidized with nitrite & & & & \\
\hline as partial electron acceptor & $f_{D N T}$ & $2.810^{-4}$ & - & g \\
\hline \multicolumn{5}{|l|}{ by heterotrophic denitrification (scenario C) } \\
\hline Fraction of nitrite or nitrate converted to & & & mol nitric & \\
\hline nitric oxide by denitrification by HET & $\varepsilon$ & 0.010 & oxide/mol $\mathrm{NO}_{\mathrm{x}}^{-}$ & g \\
\hline
\end{tabular}

${ }^{a}$ To reach the right ammonium and nitrite oxidation capacity (and thus the right $X_{\mathrm{AOB}}$ and $X_{\text {NOB }}$ ), values for $\mu_{\max }$ and $b$ were adjusted. Values for $b$ were defined as $\mu_{\max } / 7$, to identify only one parameter, and to establish values for $b$ in line with ASM2d. In ASM2d, the values for $\mu_{\max }$ and $b$ are 1 and 0.15 , respectively, for the sum of $A O B$ and $N O B$, and $b_{A O B}$ is $0.15 d^{-1}$ ( $A O B$ and NOB are not described separately in ASM2d).

${ }^{b}$ Saturation coefficient for nitrite as substrate of the denitrification pathway in $A O B$, estimated based on nitric oxide emission profile.

${ }^{c}$ Not present in ASM2d, as NOB are not separately considered. The affinity value was estimated based on the concentration profile.

${ }^{d}$ Not present in ASM2d. The affinity for oxygen is assumed to be lower for NOB than AOB (Wiesmann, 1994).

${ }^{e}$ The affinity value is relatively high $-8 \mathrm{~g} \mathrm{~N} \cdot \mathrm{m}^{-3}$ to reach the stimulating effect of nitrite availability on the nitric oxide emission.

${ }^{f} f_{p}$ is the fraction of inert solids that is generated upon biomass decay. This fraction is not made available for resolubilization and is used to account for inert solids that accumulate in the biomass. This differs from the ASM1 and 2d approach, but only has a small effect on the biomass/solids balance in the system, and no effect on the overall nitrification kinetics.

$\mathrm{g}$ The fractions for nitric oxide emission were fitted based on the nitric oxide emission profiles.

have accumulated in the medium. Therefore, the nitric oxide peak should be attributed to a metabolic response of the microorganisms in the system. Because this short-term response is a typical resultant of a temporary imbalance in the metabolism resulting from strongly changing conditions and not a structural side reaction, no further attention will be given to this.
The lower nitric oxide production level, observed as a plateau after the initial peak, shows a gradual increase, possibly corresponding to the increase in the nitrite concentration. The nitric oxide concentration in the offgas during ammonia conversion was between 0.27 and $0.55 \mathrm{ppm}$ at $0.5 \mathrm{~L} / \mathrm{min}$ airflow. This means that approximately $0.025 \%$ of the ammonium is emitted as nitric oxide. 
Table 4-Influent liquid and gas composition, bioreactor operational parameters, and physical-chemical parameter values.

\begin{tabular}{|c|c|c|c|}
\hline Parameter & Abbreviation & Value & Unit \\
\hline \multicolumn{4}{|l|}{ Influent substrate and product concentrations } \\
\hline $\begin{array}{l}\text { Oxygen } \\
\text { Ammonium } \\
\text { Nitrite } \\
\text { Nitrate } \\
\text { Carbon dioxide }\end{array}$ & $\begin{array}{l}\mathrm{S}_{\mathrm{O} 2, \text { in }} \\
\mathrm{S}_{\mathrm{NH} 4 \text {, in }} \\
\mathrm{S}_{\mathrm{NO} 2 \text {, in }} \\
\mathrm{S}_{\mathrm{NO} 3 \text {, in }} \\
\mathrm{S}_{\mathrm{CO} 2 \text { in }}\end{array}$ & $\begin{array}{l}0 \\
104 \\
0 \\
0 \\
75\end{array}$ & $\begin{array}{l}\mathrm{g} \mathrm{O}_{2} \cdot \mathrm{m}^{-3} \\
\mathrm{~g} \mathrm{~N} \cdot \mathrm{m}^{-3} \\
\mathrm{~g} \mathrm{~N} \cdot \mathrm{m}^{-3} \\
\mathrm{~g} \mathrm{~N} \cdot \mathrm{m}^{-3} \\
\mathrm{~g} \mathrm{CO}_{2} \mathrm{~m}^{-3}\end{array}$ \\
\hline $\begin{array}{l}\text { Nitric oxide concentration in gas flow } \\
\text { Oxygen concentration in gas flow }\end{array}$ & $\begin{array}{l}\mathrm{C}_{\mathrm{NO}} \\
\mathrm{C}_{\mathrm{O} 2}\end{array}$ & $\begin{array}{l}0 \\
274\end{array}$ & $\begin{array}{l}\mathrm{g} \text { nitric oxide } \cdot \mathrm{m}^{-3} \\
\mathrm{~g} \mathrm{O}_{2} \mathrm{~m}^{-3}\end{array}$ \\
\hline \multicolumn{4}{|l|}{ Reactor geometry } \\
\hline $\begin{array}{l}\text { Liquid volume at start cycle } \\
\text { Gas volume } \\
\text { Mass transfer coefficient }\end{array}$ & $\begin{array}{l}V_{L} \\
V_{G} \\
k_{l} a\end{array}$ & $\begin{array}{l}0.001 \\
0.0005 \\
300\end{array}$ & $\begin{array}{l}m^{3} \\
m^{3} \\
d^{-1}\end{array}$ \\
\hline \multicolumn{4}{|l|}{ Physical parameters } \\
\hline $\begin{array}{l}\text { Henry coefficient of nitric oxide } \\
\text { Henry coefficient for oxygen }\end{array}$ & $\begin{array}{l}\mathrm{H}_{\mathrm{NO}} \\
\mathrm{H}_{\mathrm{O} 2}\end{array}$ & $\begin{array}{l}21 \\
32.7\end{array}$ & $\begin{array}{l}M_{\text {gas }} M_{a q}^{-1} \\
M_{\text {gas }} M_{\text {aq }}^{-1}\end{array}$ \\
\hline
\end{tabular}

The nitric oxide concentration in the offgas decreased when the airflow was increased. The calculated corresponding nitric oxide saturated concentration in the liquid was between 0.21 and $0.42 \mu \mathrm{g}$ nitrogen-nitric oxide/L (based on Henry's law). Upon ammonium depletion, the nitric oxide emission immediately decreased to zero. The $\mathrm{NO}_{2}$ concentration in the offgas was below the detection limit of $0.05 \mathrm{mg} / \mathrm{L}(0.05 \mathrm{ppm})$.

The fact that an increase in nitrite concentration increases the nitric oxide emission is confirmed by nitrite pulse additions during an SBR cycle (Figure 4). A sudden increase in nitrite immediately leads to an increase in the nitric oxide production. However, when ammonia is absent, an increase in nitrite did not lead to nitric oxide production (last nitrite pulse, Figure 4). Oxygen depletion during ammonia oxidation also clearly increases nitric oxide emission (data not shown).

Model Evaluation. The three proposed nitric oxide production pathways were simulated in a mathematical model that also comprised nitrification kinetics, gas-liquid mass transfer, and reactor operation in a sequencing batch mode. Figure 5 shows that the measured ammonia, nitrite, nitrate, and oxygen conversions are very well described by the model, in all three hypotheses. The nitric oxide emission during constant ammonia and nitrite oxidation can also be described relatively well (Figure 6). The nitric oxide peak at the start of the cycle, caused by a dynamic response upon ammonia addition, cannot be explained by this kinetic model. However, the three scenarios for nitric oxide emission lead to different nitric oxide concentration profiles. In our opinion, scenario B, denitrification by $\mathrm{AOB}$, enables the best description of the experimental data. Because the nitric oxide production is linked to availability of ammonia (the electron donor for the denitrification), the nitric oxide emission ceases when ammonia is depleted. Because nitrite is the substrate for the denitrification, the emission increases with nitrite availability. Conversely, scenario A, the production of nitric oxide during nitrification, quickly leads to a fairly stable, but decreasing, nitric oxide concentration, only related to the decreasing ammonium oxidation rate. In scenario $\mathrm{C}$, the nitric oxide emission profile increases with nitrite concentration, giving a good fit in the first part of the cycle. However, the description of the second part of the cycle is not correct. The nitric oxide production continues when ammonia is depleted, because the process is linked to oxygen depletion and not dependent on ammonia availability.

\section{Discussion}

Which Process Causes the Nitric Oxide Emission? The experimental results indicate that nitric oxide is produced and emitted at the same time that ammonium oxidation takes place. This means that the cause of nitric oxide emission can be either the presence of ammonia or the limited oxygen availability resulting from oxygen consumption during ammonia oxidation. Even though 


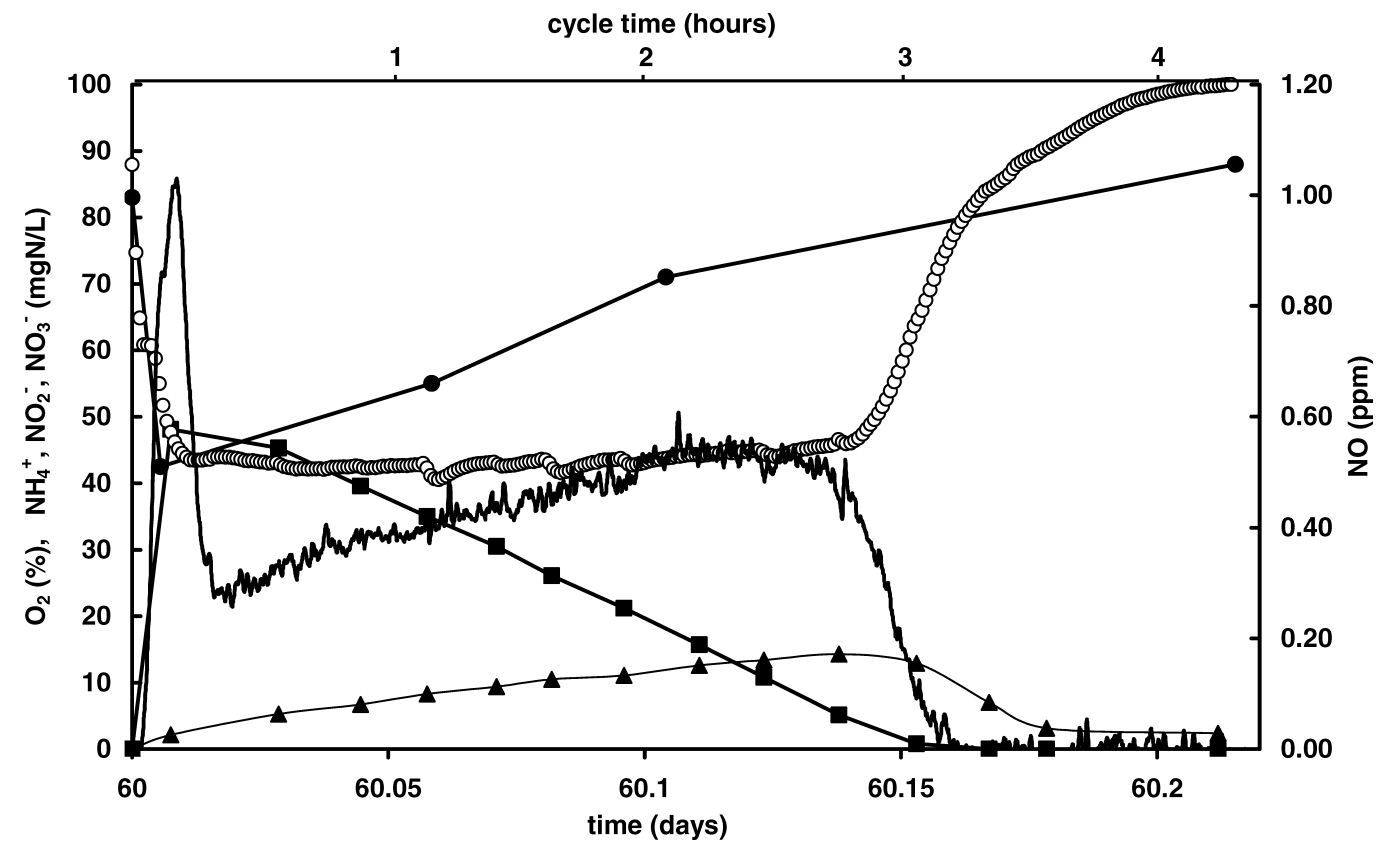

Figure 3-Liquid concentrations of oxygen $(\bigcirc)$, ammonium $\left(\mathrm{NH}_{4}^{+}-\mathrm{N}, \mathbf{\square}\right)$, nitrate $\left(\mathrm{NO}_{3}^{-}-\mathrm{N}, \bullet\right)$, nitrite $\left(\mathrm{NO}_{2}^{-} \mathrm{N}, \Delta\right)$, and offgas concentrations of nitric oxide (NO, line only) measured during a representative SBR cycle, in the steady-state conversion phase $(\mathrm{ppm}=\mathrm{mg} / \mathrm{L})$.

oxygen levels in the bioreactor are relatively high (above $4 \mathrm{mg}$ $\mathrm{O}_{2} / \mathrm{L}$ ), oxygen limitation can still occur locally within the sludge flocs. Nitric oxide could be formed chemically from nitrous acid, but this can be excluded here as a significant source, as, in that case, no ammonium or oxygen dependency would occur. Biological nitric oxide emission from nitrifying environments can, in principle, be caused by three groups of microorganisms-AOB, NOB, and heterotrophic denitrifiers. The NOB can be excluded to be responsible for the nitric oxide emission in the reactor used in this study, because nitrite oxidation still occurs after nitric oxide production has ceased and after ammonium is depleted. In AOB, two different pathways can lead to nitric oxide production. Nitric

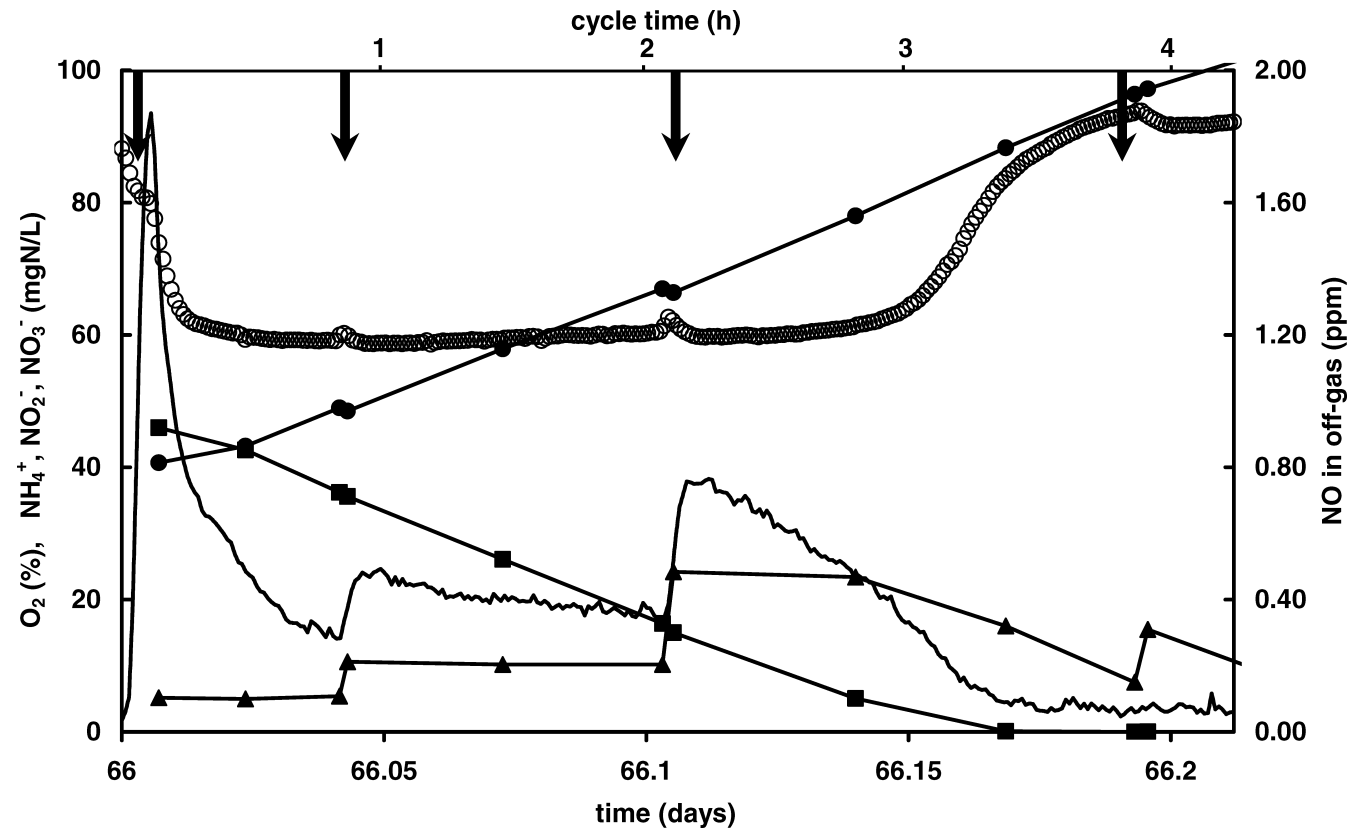

Figure 4-Liquid concentrations of oxygen $(\bigcirc)$, ammonium $\left(\mathrm{NH}_{4}^{+}-\mathrm{N}, \mathbf{\square}\right)$, nitrate $\left(\mathrm{NO}_{3}^{-}-\mathrm{N}, \bullet\right)$, nitrite $\left(\mathrm{NO}_{2}^{-} \mathrm{N}, \Delta\right)$, and offgas concentrations of nitric oxide $(\mathrm{NO},+)$ measured during an SBR cycle in which four nitrite pulse additions (indicated by arrows) are given $(\mathrm{ppm}=\mathrm{mg} / \mathrm{L})$. 

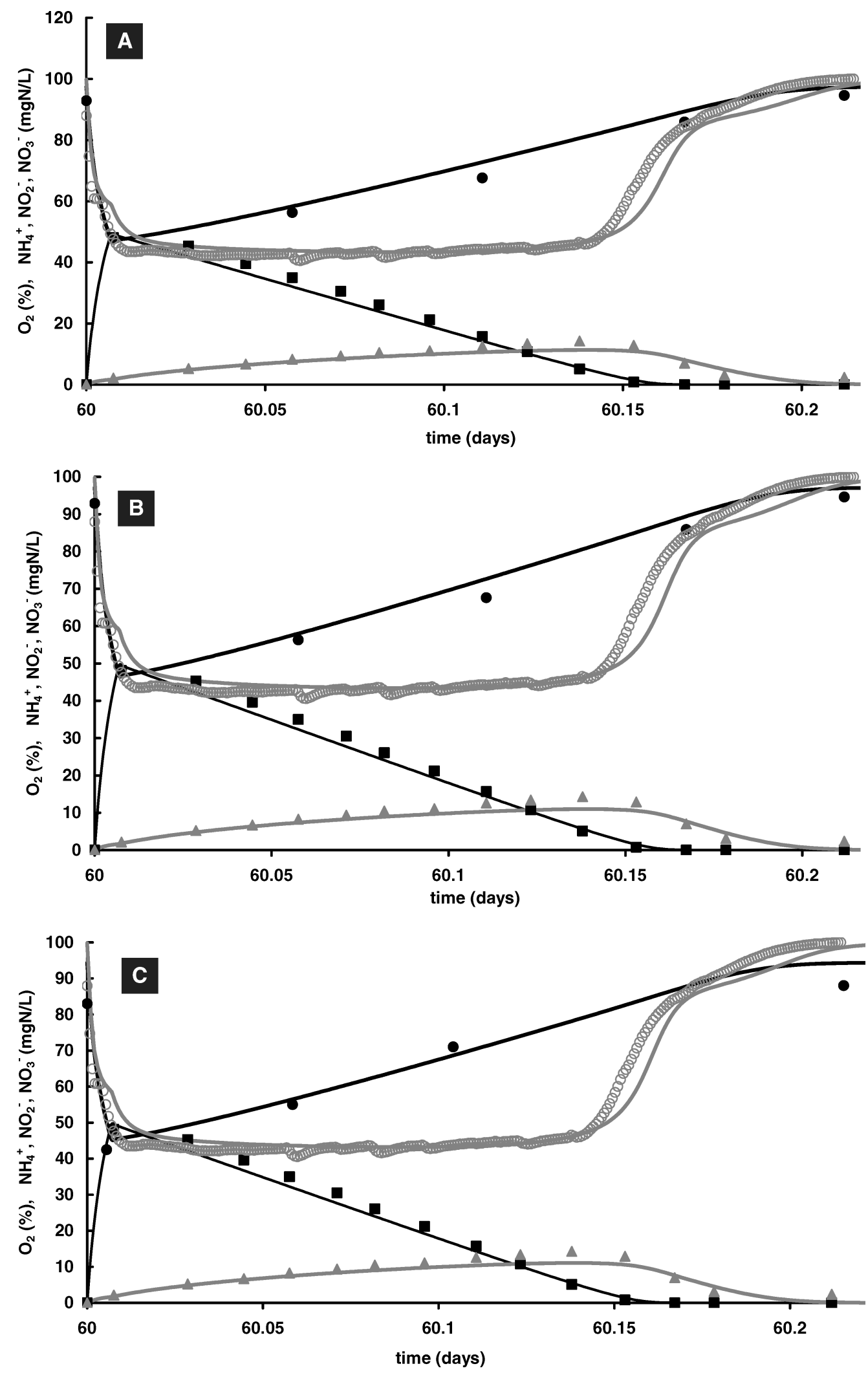

Figure 5-Simulated and measured liquid concentration profiles of oxygen $(\mathrm{O})$, ammonium $\left(\mathrm{NH}_{4}^{+}-\mathrm{N}, \mathbf{\square}\right)$, nitrate $\left(\mathrm{NO}_{3}^{-}-\mathrm{N}\right.$, $\bullet)$, and nitrite $\left(\mathrm{NO}_{2}^{-} \mathrm{N}, \mathbf{\Delta}\right)$ during a cycle after 60 days of reactor operation, when a steady nitrogen conversion is established. The three scenarios are: (a) nitrification, (b) denitrification by $A O B$, and (c) denitrification by heterotrophic bacteria. 

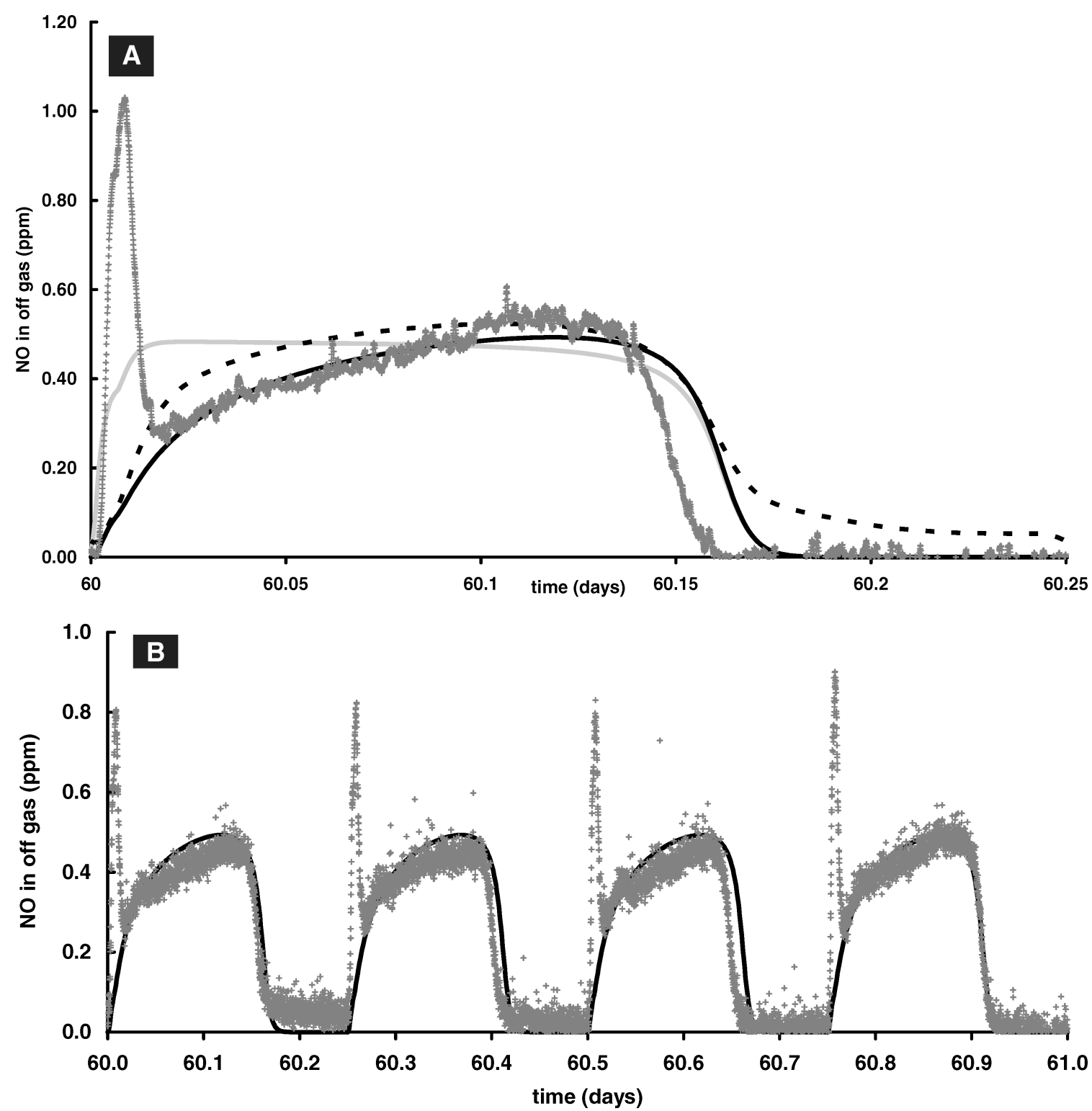

Figure 6-Simulated (lines) and measured (+) nitric oxide concentration profiles during one cycle after 60 days of reactor operation, when a steady nitrogen conversion is reached. The three scenarios simulated are: (a) nitrification (dashed line), (b) denitrification by АОВ (solid black line), (c) denitrification by heterotrophic bacteria (solid grey line). Figure 6a depicts one SBR cycle (6 hours), Figure 6b depicts four SBR cycles (1 day), and only the output from the model according to type $B$ is shown ( $p p m=m g / L)$.

oxide can escape from the oxidative pathway during the oxidation of hydroxylamine to nitrite (Ritchie and Nicholas, 1972). Alternatively, nitric oxide can be produced by denitrification by AOB, with ammonium as electron donor (Bock et al., 1995). The respiratory denitrification pathway in $\mathrm{AOB}$ probably starts with nitrite and ends at $\mathrm{N}_{2} \mathrm{O}$, as nitrite reductase and nitric oxide reductase are present in the genome of $\mathrm{AOB}$, but $\mathrm{N}_{2} \mathrm{O}$ reductase is not identified (Chain et al., 2003). In heterotrophic denitrification, nitrate and/or nitrite are reduced with organic substrates as electron donor. Both denitrification by AOB and heterotrophic denitrification are stimulated by oxygen limitation and nitrite availability. However, the need for electron donor is distinctive; AOB need ammonium, whereas heterotrophs need an organic substrate. It is possible that pathway A is also influenced by nitrite availability. Increased nitrite could lead to a higher concentration of intermediates in the oxidative pathway and consequently to a higher nitric oxide emission. This hypothesis was not considered, because there is no evidence for it in literature. In addition, our experimental data clearly showed an increased nitric oxide emission upon oxygen limitation (data not shown), thus indicating that denitrification, rather than nitrification, is the main pathway responsible for nitric oxide emission. Furthermore, other studies also suggest that the denitrification pathway in AOB (often referred to as nitrifier denitrification) is the main source of the nitric oxide and $\mathrm{N}_{2} \mathrm{O}$ emissions from AOB (Colliver and Stephenson, 2000; Schmidt et al., 2004). 
To identify which pathway is the main source of nitric oxide emission, the three possibilities ([a] oxidative pathway AOB, [b] denitrification pathway $\mathrm{AOB}$, and [c] heterotrophic denitrification) were included in a kinetic model simulating the concentration profiles obtained during the SBR cycles. The model results suggest that denitrification by $\mathrm{AOB}$ is the main nitric-oxide-producing pathway. Because nitrite is a substrate for denitrification, the profiles of scenarios $\mathrm{B}$ and $\mathrm{C}$ give the experimentally observed increase in nitric oxide emission with increase in nitrite, unlike the simulation results from the oxidative pathway $\mathrm{A}$. Because the denitrification by AOB (scenario B) is also dependent on ammonia presence, the cease in nitric oxide emission as soon as ammonia is finished is well reproduced by the model, which is not the case in model results obtained with heterotrophic denitrification (scenario C). The dependence of nitric oxide emission on nitrite concentration was also proven experimentally by the addition of nitrite pulses. A nitrite pulse does not increase the nitric oxide emission if ammonium is absent. This supports the conclusion that denitrification by $\mathrm{AOB}$ is the main pathway for nitric oxide emission in a nitrifying system.

Environmental Effects of Nitric Oxide Emission by Nitrifying Wastewater Treatment Plants. This study strongly indicates that, in a nitrifying reactor treating wastewater containing solely ammonium and nutrients, denitrification by AOB is the main nitricoxide-producing pathway. From the experiments, it can be concluded that approximately $0.025 \%$ of the ammonium is emitted as nitric oxide. Because of the presence of organic substrate in wastewater, heterotrophic denitrification is a dominant process that will also cause nitric oxide emission. However, nitric oxide can also be consumed during heterotrophic denitrification, because it is an intermediate. The nitric oxide emission by AOB denitrification is dependent on many process conditions, such as oxygen concentration, ammonium availability, and nitrite concentration. The heterotrophic denitrification will also depend on oxygen and nitrite concentration and additionally on the availability of organic substrate and nitrate.

In the nitrifying system described here, nitric oxide is mainly produced in the denitrification pathway of AOB. The end product of this pathway likely is $\mathrm{N}_{2} \mathrm{O}$ (a significant greenhouse gas), which is expected to be produced also, increasing the negative effect on the atmosphere. The $\mathrm{N}_{2} \mathrm{O}$ emission is predicted to be higher than the nitric oxide emission, because nitric oxide is an intermediate, and $\mathrm{N}_{2} \mathrm{O}$ is the final product of the AOB denitrification pathway. The occurrence of $\mathrm{N}_{2} \mathrm{O}$ emission from our experimental setup during ammonia oxidation has been confirmed by preliminary measurements.

Nitric oxide could also lead to health risks for operators of WWTPs. The maximum allowable concentration value for nitric oxide in the Netherlands is currently $25 \mathrm{ppm}$ in the gas phase but will be lowered to $0.2 \mathrm{ppm}$. In our experiments, the nitric oxide concentration in the offgas of the reactor was between 0.2 and 1 ppm during nitrification. The ammonium concentration at the beginning of the cycle (50 mg nitrogen/L) was comparable to those found in the influent of municipal WWTPs. In full-scale plants, the volumetric aeration (cubic meters of air per cubic meters of water) is much lower than used in our experiments. We found that when the gas flowrate was decreased (from 0.8 to $0.4 \mathrm{~L} / \mathrm{min}$ ) in the experimental setup, the nitric oxide concentration increased proportionally. This suggests that nitric oxide concentrations in the offgas of full-scale nitrifying WWTPs may reach significantly higher values than those described here.
Waste streams that contain high nitrogen concentrations, such as sludge water or manure, are expected to have a higher nitric oxide concentration in the offgas of the treatment plants. This is caused by the lower gas feed compared with nitrogen load, higher volumetric nitrifying activity, and possibly more accumulation of nitrite. More attention to these emissions is needed because of potential health risks for personnel at the plants.

Applicability of the Kinetic Model for Wastewater Treatment Plant Practice. The purpose of the model developed in this study was to identify the main nitric-oxide-producing pathway. However, we believe that the model of scenario $\mathrm{B}$-nitric oxide emission by denitrification by $\mathrm{AOB}$ - can be used to predict nitric oxide emission by nitrifying cultures in WWTPs. This kinetic model has also limitations; for example, the sharp increase in nitric oxide production because of the sudden availability of ammonium after a period of starvation cannot be modeled from the present assumptions. The sudden nitric oxide production is probably caused by imbalanced startup of the ammonia oxidation pathway, which should be modeled in a more complex metabolic model. The specific parameters $f_{\mathrm{DNT}}$ and $\beta$, which were derived to generate a satisfying fit of the model with the experimental nitric oxide emission data, can be used as an indication for the amount of nitric oxide produced. However, as these parameters cannot be separately identified, the absolute values are unreliable. The conversions predicted by the model generate a good fit with the experimental conversion. After validation of the emission parameters in several nitrifying conditions (i.e., testing the influence of gas flow, oxygen depletion, and nitrogen load), this approach can be used as an extension of existing activated sludge models (Henze et al., 1999) for the prediction of gaseous nitrogen oxides emissions.

\section{Conclusions}

This study strongly suggests that, in a nitrifying reactor treating wastewater containing solely ammonium and nutrients, denitrification by AOB is the main nitric-oxide-producing pathway. This was determined by combining measurements in a nitrifying laboratoryscale reactor with kinetic modeling. By emission of nitric oxide (and probably $\mathrm{N}_{2} \mathrm{O}$, which is produced in the same pathway), WWTPs may have a negative effect on the greenhouse effect, and health risks for personnel should be considered. The presented modeling approach can be used as an extension of the ASM models to predict gaseous emissions from WWTPs.

\section{Credits}

The authors thank Caroline Dirksz (Rotterdam University, Netherlands) for her help with the experimental work. The project was funded by the Dutch Foundation for Applied Research (Utrecht, Netherlands) (STW, grant NBC6352).

Submitted for publication January 31, 2007; revised manuscript submitted July 5, 2007; accepted for publication July 11, 2007.

The deadline to submit Discussions of this paper is March 15, 2008.

\section{References}

American Public Health Association; American Water Works Association; Water Pollution Control Federation (1985) Standard Methods for the Examination of Water and Wastewater, 16th ed.; American Public Health Association: Washington, D.C. 
Bock, E.; Schmidt, I.; Stuven, R.; Zart, D. (1995) Nitrogen Loss Caused by Denitrifying Nitrosomonas Cells Using Ammonium or Hydrogen as Electron Donors and Nitrite as Electron Acceptor. Arch. Microbiol., 163 (1), 16-20.

Bock, E.; Wagner, M. (2001) Oxidation of Inorganic Nitrogen Compounds as an Energy Source. In The Prokaryotes-An Evolving Electronic Resource for the Microbiological Community, Dworkin, M., Falkow, S., Rosenberg, E., Schleifer, K.-H., Stackebrandt, E. (Eds.); Springer: New York.

Chain, P.; Lamerdin, J.; Larimer, F.; Regala, W.; Lao, V.; Land, M.; Hauser, L.; Hooper, A.; Klotz, M.; Norton, J.; et al. (2003) Complete Genome Sequence of the Ammonia-Oxidizing Bacterium and Obligate Chemolithoautotroph Nitrosomonas europaea. J. Bacteriol., 185 (9), 2759-2773.

Colliver, B. B.; Stephenson, T. (2000) Production of Nitrogen Oxide and Dinitrogen Oxide by Autotrophic Nitrifiers. Biotechnol. Adv, 18 (3), 219-232.

Crutzen, P. J. (1979) The Role of Oxides of Nitrogen (NO, NO2) in the Chemistry of the Troposphere and Stratosphere. Ann. Rev. Earth Planet. Sci., 7, 443-472.

Firestone, M. K.; Firestone, R. B.; Tiedje, J. M. (1979) Nitric Oxide as an Intermediate in Denitrification: Evidence from Nitrogen-13 Isotope Exchange. Biochem. Biophys. Res. Comm., 91 (1), 10-16.

Freitag, A.; Bock, E. (1990) Energy Conservation in Nitrobacter. FEMS Microbiol. Lett., 66 (1-3), 157-62.

Henze, M.; Gujer, W.; Mino, T.; Matsuo, T.; Wentzel, M. C.; Marais, G. v. R.; Van Loosdrecht, M. C. M. (1999) Activated Sludge Model No. 2D, ASM2D. Water Sci. Technol., 39 (1), 165-182.
Konneke, M.; Bernhard A. E.; de la Torre, J. R.; Walker, C. B.; Waterbury, J. B.; Stahl, D. A. (2005) Isolation of an Autotrophic AmmoniaOxidizing Marine Archaeon. Nature, 437 (7058), 543-546.

Lipschultz, F.; Zafiriou, O. C.; Wofsy, S. C.; McElroy, M. B.; Valois, F. W.; Watson, S. W. (1981) Production of Nitric Oxide and Nitrous Oxide by Soil Nitrifying Bacteria. Nature, 294 (5842), 641-643.

Marletta, M. A.; Tayeh, M. A.; Hevel, J. M. (1990) Unraveling the Biological Significance of Nitric Oxide. BioFactors, 2 (4), 219-225.

Reichert, P. (1998) AQUASIM 2.0-User Manual; Swiss Federal Institute for Environmental Science and Technology: Dübendorf, Switzerland.

Ritchie, G. A. F.; Nicholas, D. J. D. (1972) Identification of the Sources of Nitrous Oxide Produced by Oxidative and Reductive Processes in Nitrosomonas europaea. Biochem. J., 126 (5), 1181-1191.

Schmidt, I.; van Spanning, R. J. M.; Jetten, M. S. M. (2004) Denitrification and Ammonia Oxidation by Nitrosomonas europaea Wild-Type, and NirK- and NorB-Deficient Mutants. Soc. Gen. Microbiol., 150 (12), 4107-4114.

Stuven, R.; Bock, E. (2001) Nitrification and Denitrification as a Source for NO and NO2 Production in High-Strength Wastewater. Water Res., 35 (8), 1905-1914.

Wiesmann, U. (1994) Biological Nitrogen Removal from Wastewater. $A d v$. Biochem. Eng. Biotechnol., 51, 113-154.

Yoshinari, T. (1985) Nitrite and Nitrous Oxide Production by Methylosinus trichosporium. Can. J. Microbiol., 31 (2), 139-144.

Zumft, W. G. (1993) The Biological Role of Nitric-Oxide in Bacteria. Arch. Microbiol., 160 (4), 253-264. 